JOURNAL OF MANAGEMENT OF AQUATIC RESOURCES.

Volume 1, Nomor 1, Tahun 2012, Halaman 1-8

Online di : http://ejournal-s1.undip.ac.id/index.php/maquares

\title{
KEBIASAAN MAKAN TERIPANG (ECHINODERMATA: HOLOTHURIIDAE) DI PERAIRAN PANTAI PULAU PRAMUKA, KEPULAUAN SERIBU
}

\author{
Oriza Ruzfi Agusta, Bambang Sulardiono, Siti Rudiyanti *)
}

Jurusan Perikanan Fakultas Perikanan dan Ilmu Kelautan Universitas Diponegoro

Jl. Prof. H. Soedharto, SH, Tembalang Semarang. 50275 Telp/Fax (024) 7474698

\begin{abstract}
Abstrak
Teripang adalah biota laut yang bergerak lambat, hidup pada dasar substrat pasir, pasir berlumpur maupun dalam lingkungan terumbu yang. merupakan salah satu sumber protein hewani dan telah lama dikonsumsi oleh masyarakat di dalam maupun di luar negeri. Penelitian dilaksanakan pada bulan April 2012 di Perairan pantai Pulau Pramuka, Kepulauan Seribu. Identifikasi kebiasaan makan teripang dilakukan di Laboratorium Hidrobiologi Fakultas Perikanan dan Ilmu Kelautan Universitas Diponegoro. Tujuan dari penelitian ini adalah Mengetahui kebiasaan makanan teripang di Perairan pantai Pulau Pramuka, Kepulauan Seribu. Pada penelitian ini, menggunakan metode Index of Preponderance. Nilai Index of Preponderance diketahui dengan cara mengamati makanan yang terdapat pada usus Teripang. Teknik sampling teripang yang digunakan dalam penelitian ini adalah metode sensus. Hasil penelitian didapatkan, saat sampling di lapangan diperoleh 3 spesies teripang yaitu Holothuria hilla, Holothuria leucospilota, Holothuria impatiens. Makanan utama dari ke tiga jenis teripang yang di temukan adalah jenis Bacillariophyceae dengan nilai Index of Preponderance masing-masing jenis sebesar Holothuria hilla 51\%, Holothuria leucospilota 35, $1 \%$ dan Holothuria impatiens 52,5\%.
\end{abstract}

Kata kunci : Kebiasaan makanan, Pulau Pramuka, Teripang

\begin{abstract}
Sea cucumbers are types of sea animals that move slowly, living on the bottom substrate of sand, silt and in the reef environment that one source of animal protein and have long been consumed by people within and outside the country. The research was conducted in April 2012 in the coastal waters of Pramuka Island, Seribu Islands. Identification of the feeding habits of sea cucumbers performed performed in the Laboratory of Hydrobiology Faculty of Fisheries and Marine Science Diponegoro University. The purpose of this study is to food habits of sea cucumber in the waters of the Pramuka Island, Seribu Island. In this study, using the method Index of Preponderance. Value Index of Preponderance is know by observing that there is food in the gut cucumber. The sampling technique used for sea cucumber in this study is the census method. The results obtained when sampling in the field gets the 3 species of sea cucumber are Holothuria hilla, Holothuria leucospilota, Holothuria impatiens. The main meal of the three types of the sea cucumber found such as Bacillariophyceae which have I Index of Preponderance value of each type of Holothuria hilla is 51\%, Holothuria leucospilota is 35,1\% and Holothuria impatiens is 52,5\%.
\end{abstract}

Key words : Food Habits, Pramuka Island, Sea Cucumber

\section{Pendahuluan}

Teripang adalah salah satu kelompok echinodermata yang mempunyai arti ekonomis penting. Teripang merupakan komponen penting dalam rantai makanan di terumbu karang dan ekosistem asosiasinya pada berbagai tingkat struktur pakan (trophic levels). Teripang berperan penting sebagai pemakan deposit (deposit feeder) dan pemakan suspensi (suspension feeder) (Setiawan, 2010). Didalam keterkaitannya dengan sistem rantai makanan maka terdapat kecenderungan suatu spesies mempunyai tingkat kesukaan makanan terhadap jenis tertentu, tetapi informasi penelitian tentang kebiasaan makan pada jenis teripang khususnya pada famili holothuriidae di Kepulauan Seribu belum banyak dilakukan. Mengingat pentingnya kebiasaan makan secara ekologis untuk dapat diketahui sebagai bahan pengelolaan, maka penelitian ini dilakukan. Tujuan dari penelitian yang dilaksanakan pada bulan April 2012 ini adalah untuk mengetahui jenis-jenis makanan teripang dan mengetahui kebiasaan makan teripang di Perairan pantai Pulau Pramuka, Kepulauan Seribu.

\footnotetext{
${ }^{*}$ Penulis Penanggung Jawab
} 


\section{Materi dan Metode}

A. Materi Penelitian

Materi yang digunakan dalam penelitian ini adalah teripang dari genus Holothuria. Pengambilan Sampel dilakukan di Perairan pantai Pulau Pramuka, Kepuluan Seribu. Sampel teripang dikoleksi langsung dari alam yang berada di ekosistem karang.

\section{B. Metode Penelitian dan Analisis Data}

Metode Sampling

Teknik sampling yang digunakan dalam penelitian ini adalah metode sensus. Sampling dilakukan di ekosistem terumbu karang dan mengambil semua teripang yang ditemukan di lapangan. Menurut Prasetyo dan Jannah (2005) dalam Haryanto (2011), Teknik sampling dengan cara sensus dipakai dengan tujuan agar dapat memperoleh informasi yang lebih lengkap tentang kondisi sebenarnya, karena seluruh populasi diselidiki tanpa terkecuali. Alasan lain metode ini digunakan yaitu jumlah populasi dianggap tidak terlalu banyak. Cara sensus ini biasanya dikenal dengan istilah total sampling atau Complete Enumeration yang digunakan jika jumlah populasi dari suatu penelitian tidak terlalu banyak.

\section{Identifikasi Organ Pencernaan}

Metode analisis organ pencernaan pada teripang dilakukan dengan cara sampel teripang yang diperoleh dari hasil penelitian disectio bagian tubuhnya menjadi dua bagian, kemudian diambil organ perncernaannya lalu diawetkan dengan formalin $4 \%$. Metode mengidentifikasi jenis makanan, dilakukan dengan cara mengambil usus dan mengeluarkan isi usus tersebut lalu mengencerkan dengan akuadest, kemudian mengidentifikasi isi usus yang diambil dengan pipet dan dituangkan dalam Sedgwick rafter kemudian diamati di bawah mikroskop dengan perbesaran 10 x 40 .

\section{Analisis Data}

Menganalisa kebiasaan makan teripang digunakan metode sebagai berikut:

Metode frekuensi kejadian (Efendie et al, 1979)

$$
\operatorname{Fr}=\frac{L i}{L t} \times 100 \%
$$

Fr $\quad=$ Frekuensi kejadian satu macam makanan

$\mathrm{Li}=$ Jumlah makanan per jenis dalam organ perncernaan

$\mathrm{Lt}=$ Jumlah total organ pencernaan yang berisi makanan

Metode Index of Preponderance (Effendi, 2002)

$$
\begin{array}{ll} 
& \mathrm{IP}=\left(\frac{\text { vi x oi }}{\sum(\text { vi x oi })}\right) \times 100 \% \\
\text { IP } & =\text { Indeks utama }(\text { Index of Preponderance }) \\
\text { ni } & =\text { Persentase volume satu macam makanan } \\
\text { oi } & =\text { Persentase frekuensi kejadian satu macam makanan } \\
\left.\sum \text { (ni x oi }\right) & =\text { Jumlah ni } x \text { oi dari semua jenis makanan }
\end{array}
$$

Isi pencernaan teripang terdiri dari organisme kecil sehingga mengalami keterbatasan dalam menentukan volume masing-masing makanan, sehingga dilakukan modifikasi rumus Indeks of Preponderance, untuk menentukan Indeks of Preponderance menggunakan metode numerical. IP dihitung dengan rumus:

$$
\mathrm{IP}=\left(\frac{\text { ni } \times \text { oi }}{\left.\sum \text { (ni } \times \text { oi }\right)}\right) \times 100 \%
$$

ni $\quad=$ Persentase numerical satu macam makanan

\section{Hasil dan Pembahasan}

\section{Deskripsi Spesies}

Berdasarkan hasil sampling lapangan yang dilakukan di Pulau Pramuka, Kepulauan Seribu, jenis-jenis teripang yang ditemukan adalah famili Holothuriidae yaitu $H$. hilla, $H$. leucospilota dan $H$. impatiens. Famili Holothuriidae memiliki penampang tubuh bulat atau sedikit memipih dibagian ventralnya. Tapi lubang anusnya rata atau halus atau bergelombang, atau dengan gigi-gigi yang mengelilinginya (Purwati dan Wirawati, 2009).
a. H. hilla
Filum : Echinodermata
Kelas : Holothuroidea
Ordo : Aspidochirotida 
Famili : Holothuriidae

Genus : Holothuria

Spesies : H. hilla Lesson, 1830

Tubuhnya langsing dan lentur serta mempunyai papilla berwarna terang, tetapi pada beberapa individu papillanya agak berwarna gelap. Tentakelnya pendek dan berwarna bening. Pada siang hari teripang ini pada umumnya menyembunyikan diri di bawah bebatuan, aktif bergerak hanya pada malam hari saja. Holothuria hilla tidak termasuk kedalam kelompok teripang yang mempunyai nilai jual (Setyastuti, 2009).

$\begin{array}{ll}\text { b. } & \text { H. leucospilota } \\ \text { Filum } & \text { : Echinodermata } \\ \text { Kelas } & \text { : Holothuroidea } \\ \text { Ordo } & \text { : Aspidochirotida } \\ \text { Famili } & \text { : Holothuriidae } \\ \text { Genus } & : \text { Holothuria } \\ \text { Spesies } & \text { H. leucospilota Brandt, } 1835\end{array}$

Teripang keling atau teripang getah (Holothuria leucospilota) atau yang dulu dikenal dengan nama latin Holothuria vagabunda memiliki ciri morfologis yang menonjol yaitu bentuk badan silindris memanjang berwarna hitam, tubuhnya lembut, lentur, dan ditutupi dengan papilla lembut, apabila dalam keadaan kontraksi berbentuk buah pir, tegumen lunak, dan memiliki tabung cuvierian (Conand, 1998 dalam Hana, 2011).

$\begin{array}{ll}\text { c. } & \text { H. impatiens } \\ \text { Filum } & \text { : Echinodermata } \\ \text { Kelas } & \text { : Holothuroidea } \\ \text { Ordo } & \text { : Aspidochirotida } \\ \text { Famili } & \text { : Holothuriidae } \\ \text { Genus } & \text { : Holothuria }\end{array}$

Spesies : H. impatiens Forskal, 1775

H. impatiens memiliki tubuhnya yg lunak dan fleksibel serta kaki tabung yang terlihat jelas. Spesies ini biasanya ditemukan di perairan tropis yang dangkal, terutama yang berada di terumbu karang pada kedalaman tidak lebih dari 40 meter. Jarang dari spesies ini ditemukan panjangnya hingga $30 \mathrm{~cm}$, dan spesies ini juga ditandai dengan permukaan yang bergelombang merah muda dan keabu-abuan (ETI BioInformatics, 2006).

\section{Persentase komposisi makanan}

Berdasarkan hasil sampling lapangan yang dilakukan di Pulau Pramuka, Kepulauan Seribu, ditemukan 5 buah teripang dari famili Holothuriidae. Jenis-jenis teripang yang ditemukan yaitu H. hilla, H. leucospilota dan $H$. impatiens. Persentase komposisi makanan pada teripang dapat digambarkan melalui diagram sebagai berikut :

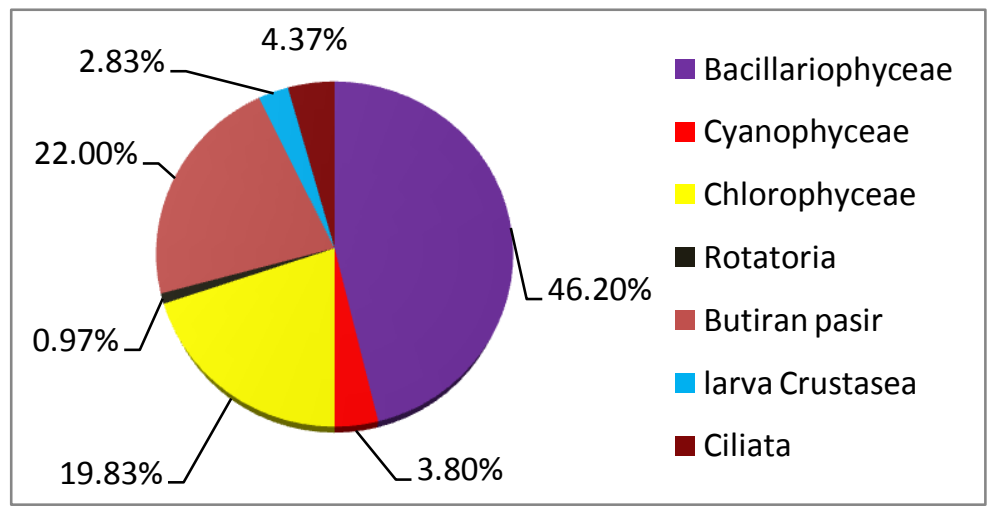

Gambar 1. Diagram Persentase Komposisi Makanan

Diagram persentase komposisi makanan pada gambar 1 secara keseluruhan menunjukkan bahwa nilai persentase terbesar adalah Bacillariophyceae yaitu sebesar 46,20\% dan terkecil adalah Rotatoria yaitu sebesar 0,97\%. 


\section{Hasil index of preponderance}

Data yang diperoleh dari hasil pengamatan berupa nilai index of preponderance. disajikan pada tabel 1 dan gambar 1 di bawah ini :

Tabel 1. Hasil Pengamatan Isi Perut Teripang

\begin{tabular}{llccc}
\hline \multirow{2}{*}{ No } & \multirow{2}{*}{ Jenis makanan } & \multicolumn{3}{c}{ Jenis Teripang } \\
\cline { 3 - 5 } & & H. hilla & H. leucospilota & H. impatiens \\
\cline { 3 - 5 } 1. & Bacillariophyceae & 51 & $\mathrm{IP}(\%)$ & $\mathrm{IP}(\%)$ \\
2. & Cyanophyceae & 0,6 & 35,1 & 52,5 \\
3. & Chlorophyceae & 18,2 & 7,4 & 3,4 \\
4. & Rotatoria & 1,1 & 23,3 & 18 \\
5. & Butiran pasir & 20 & 1,1 & 0,7 \\
6. & Larva Crustacea & 8 & 24,8 & 21,2 \\
7. & Ciliata & 1,1 & 0,3 & 0,2 \\
\hline \multicolumn{6}{r}{ Jumlah } & 100 & 8 & 4 \\
\hline
\end{tabular}

Data pada Tabel 1 menunjukkan terdapat kesamaan jenis makanan teripang yang ditemukan pada $H$. hilla, $H$. leucospilota dan $H$. impatiens yaitu Bacillariophyceae, Cyanophyceae, Chlorophyceae, Rotatoria, butiran pasir, larva Crustacea dan Ciliata.

Dari nilai index of preponderance pada tabel 1 diperoleh histogram persentase index of preponderance pada masing-masing jenis teripang sebagai berikut :

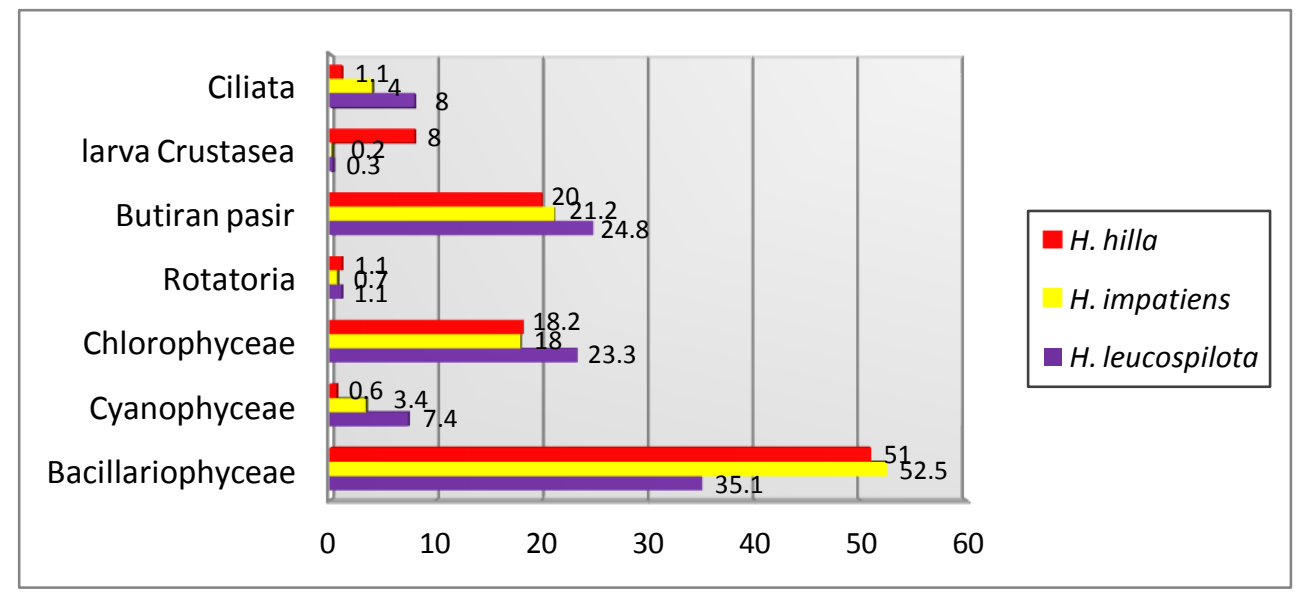

Gambar 2. Histogram Nilai Index Of Preponderance

Hasil pada gambar 2 histogram nilai index of preponderance pada masing-masing jenis teripang yaitu pada $H$. hilla Bacillariophyceae merupakan persentase yang paling tinggi yaitu $51 \%$ dan jenis makanan yang paling rendah yaitu Cyanophyceae dengan nilai persentase $0,6 \%$. H. leucospilota persentase yang paling tinggi adalah Bacillariophyceae sebesar 35,1\% dan yang paling rendah larva Crustacea sebesar 0,3\%. Pada $H$. impatiens persentase yang paling tinggi adalah Bacillariophyceae sebesar 52,5\% dan yang paling rendah larva Crustacea sebesar $0,2 \%$

\section{Hasil uji similaritas}

Hasil uji similaritas menggunakan uji Levene's Test digunakan untuk mengetahui kecenderungan kesukaan makan antar spesies terhadap jenis makanan.

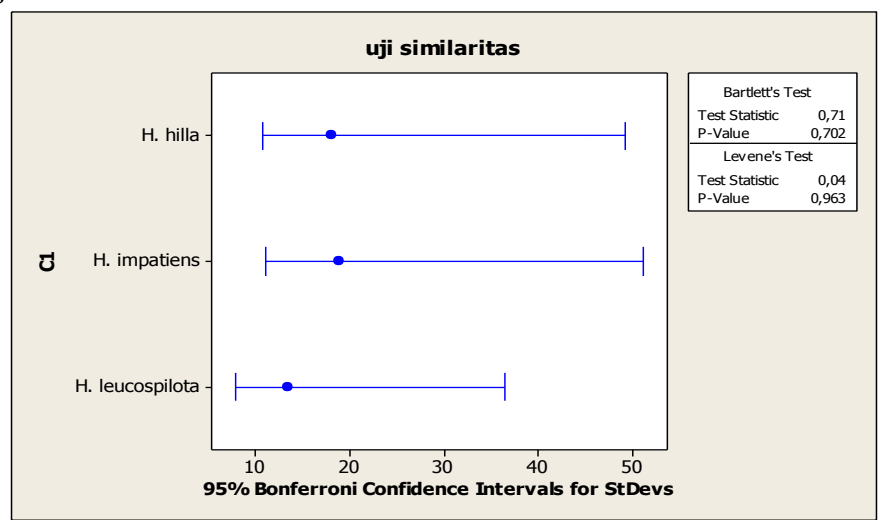


Gambar 3. Hasil Uji Similaritas Levene's Test

Hasil uji Similaritas Levene's Test diperoleh nilai signifikansi 0,963 sehingga terima $\mathrm{H}_{0}$ artinya antar spesies memiliki kecenderungan yang sama pada jenis makanan.

\section{Hasil parameter kualitas air}

Hasil parameter kualitas air yang diperoleh saat sampling di lapangan adalah sebagai berikut :

Tabel 2. Hasil Parameter Kualitas Air

\begin{tabular}{ccc}
\hline Parameter & Hasil & Kisaran toleransi \\
\hline Suhu $\left({ }^{\circ} \mathrm{C}\right)$ & $28-30$ & $27^{\circ} \mathrm{C}-30^{\circ} \mathrm{C}$ (Lewerissa, 2009) \\
Kedalaman $(\mathrm{cm})$ & $50-90$ & $0,5-1$ meter (Notowinarto, 1992 dalam Gultom \\
& & 2004) \\
Arus $(\mathrm{m} / \mathrm{s})$ & $0,3-0,4$ & $0,30-0,50$ (Martoyo, et al, 2006) \\
Salinitas $(\mathrm{ppt})$ & 31 & $30-37 \%$ (Martoyo, et al, 2006) \\
$\mathrm{pH}$ & 7 & $6,5-8,5$ (Wibowo et al, 1997) \\
\hline
\end{tabular}

Hasil parameter kualitas air pada tabel 2 seperti suhu, kedalaman, arus, salinitas dan $\mathrm{pH}$ menunjukkan bahwa semua parameter masih dalam batas toleransi untuk kehidupan teripang.

\section{Hasil kandungan substrat perairan}

Berdasarkan hasil analisa substrat yang dilakukan di Laboratorium Mekanika Tanah, Fakultas Teknik Universitas Diponegoro didapatkan karakteristik substrat yakni pada histogram dibawh ini.

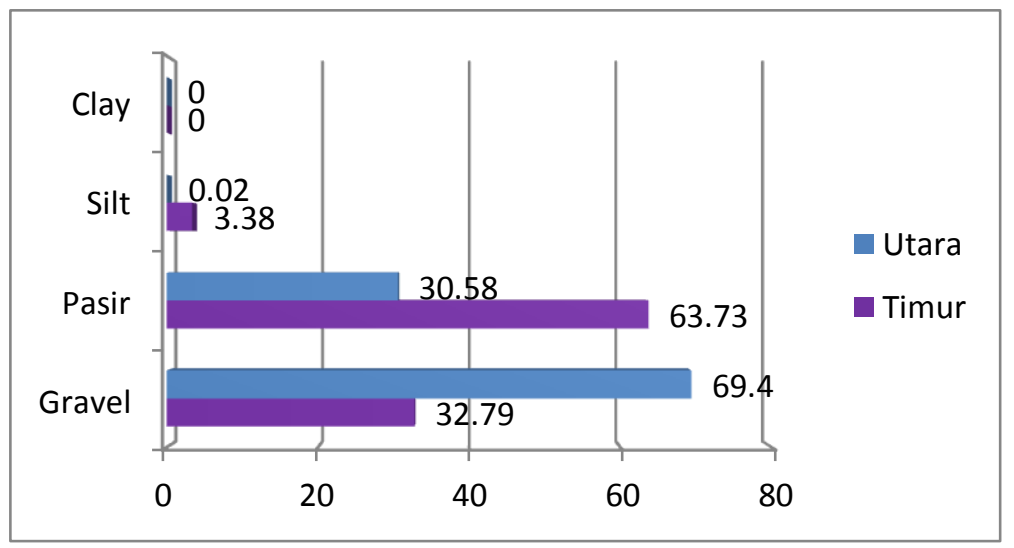

Gambar 4. Histogram Hasil Kandungan Substrat Perairan

Hasil histogram kandungan substrat perairan pada gambar 3, pada lokasi pengamatan sebelah utara memiliki kandungan gravel yaitu $69,4 \%$, pasir $30,58 \%$, silt $0,02 \%$ dan clay $0,00 \%$. Lokasi pengamatan sebelah timur memiliki kandungan gravel yaitu $32,79 \%$, pasir $63,73 \%$, silt $3,38 \%$ dan clay $0,00 \%$.

\section{Pembahasan}

\section{Persentase komposisi makanan}

Secara keseluruhan persentase komposisi jenis makanan, Bacillariophyceae dari famili diatom merupakan jenis makanan yang mempunyai nilai tertinggi dibandingkan makanan jenis lainnya. Dimana nilai Bacillariophyceae sebesar 46,20\%. Menurut Yusron dan Sjafei (1997), makanan utama teripang dari genus Holothuride adalah plankton dari kelompok diatom.

Jenis makanan lainnya hanya memiliki persentase sebasar 0,97 - 19,83\% saja. Butiran pasir juga mendominasi di dalam organ pencernaan pada genus Holothuria yang memiliki persentase sebesar 22\%. Menurut Martoyo et al (1994), makanan utama teripang adalah organisme-organisme kecil, detritus (sisa-sisa pembusukan bahan organik), dan diatom. Jenis makanan lainnya adalah radiolaria, foraminifera, partikel-partikel pasir ataupun hancuran-hancuran karang.

\section{Index of preponderance (index bagian terbesar makanan)}

Penelitian pola kebiasaan makan teripang yang dilakukan dari 3 jenis teripang pada daerah rataan terumbu karang di Pulau Pramuka menunjukkan bahwa jenis $H$. hilla dengan panjang usus $42 \mathrm{~cm}$, panjang tubuh $38 \mathrm{~cm}$ dan berat 316 gram yang memiliki tentakel tipe digitate atau tentakel berbentuk jari, pada isi perut teripang ini didominasi oleh Bacillariophyceae dari famili diatom dengan nilai IP 51\%, Chlorophyceae memiliki nilai IP yaitu 18,2\%, larva Crustacea dengan nilai IP 8\%, Rotatoria dengan nilai IP 1,1\%, Ciliata dengan nilai IP 1,1\% dan yang terkecil yaitu 
Cyanophyceae dengan IP 0,6\%. Menurut Aziz (1996), tentakel bukal berbentuk jari (digitate) dimiliki oleh teripang bangsa Aspidochirotida merupakan ciri dari teripang pemakan endapan (deposit feeder), dengan sumber makanan utamanya berupa kandungan zat organik dalam lumpur, detritus dan plankton.

H. leucospilota ditemukan 2 individu di sebelah timur Pulau Pramuka. Individu pertama memiliki panjang usus $40 \mathrm{~cm}$, panjang tubuh $30 \mathrm{~cm}$ dan berat 332 gram. Individu kedua memiliki panjang usus $46 \mathrm{~cm}$, panjang tubuh $36 \mathrm{~cm}$, dan berat 363 gram. Pada organ pencernaan nya ditemukan beberapa macam jenis makanan yaitu Bacillariophyceae, Cyanophyceae, Chlorophyceae, Rotatoria, Larva Crustacea, dan Ciliata. Nilai IP terbesar 35,1\% yaitu dari kelas Bacillariophyceae dari famili diatom dan yang terkecil yaitu Larva Crustacea dengan nilai IP 0,3\%. Dimana didalam isi usus teripang menggambarkan bahwa makanan yang didapatkan berukuran relatif sangat kecil. Menurut Yusron dan Sjafei (1997), kebiasaan makan teripang terdiri dari organisme-organisme kecil dan dapat menggambarkan kondisi lingkungan dimana teripang hidup.

Jenis terakhir yang ditemukan yaitu $H$. impatiens dengan jumlah 2 individu. Individu pertama memiliki panjang usus $23 \mathrm{~cm}$, panjang tubuh 20,5 cm dan berat 94 gram. Individu kedua memiliki panjang usus $21 \mathrm{~cm}$, panjang tubuh $19 \mathrm{~cm}$, dan berat 71 gram milikili. Sama seperti dua jenis teripang sebelumnya pada teripang jenis $H$. impatiens jenis makanan yang memiliki nilai IP terbesar adalah Bacillariophyceae. Nilai IP terkecil 0,2\% pada jenis makanan Larva Crustacea. Menurut Feral (1989) dalam Aziz (1996), melaporkan bahwa Teripang bisa dianggap sebagai biota omnivora, karena sumber makanannya bisa berasal dari sisa tanaman ataupun sisa hewan.

Selain organisme plankton didalam alat pencernaan $H$. hilla, $H$. leucospilota dan $H$. impatiens ditemukan pasir yang memiliki persentase yang cukup besar. Teripang tidak memakan partikel ini namun hanya memanfaatkan bakteri yang berasosiasi dengan detritus organik yang diekstrak dari sejumlah substrat yang ditelan, sehingga pasir hanya sebagai media masuknya makanan yang terkandung didalamnya. Substrat dan partikel lain yang tidak dimanfaatkan atau dicerna oleh teripang akan dikeluarkan kembali ke perairan melalui anus tanpa menimbulkan kerusakan pada saluran pencernaanya.

Makanan utama dari kedua jenis teripang yang di temukan adalah kelas Bacillariophyceae dengan nilai IP masing-masing jenis sebesar $H$. hilla 51\%, H. leucospilota 35,1\% dan $H$. impatiens 52,5\%. Menurut Haryadi (1983), Apabila nilai IP lebih besar dari 25\%, pakan tersebut merupakan pakan utama. Apabila nilai IP antara $4-25 \%$, pakan tersebut merupakan pakan pelengkap, dan apabila IP bernilai kurang dari 4\%, pakan tersebut merupakan pakan tambahan.

H. hilla, H. leucospilota dan H. impatiens Berdasarkan hasil penelitian dapat dikatakan bahwa teripang memiliki peranan untuk meningkatkan biodiversity karena untuk beradaptasi terhadap panas genus Holothuria mengguling-gulingkan badannya dan mengaduk-aduk substrat untuk mencari makan, sehingga akan membuat subsrat menjadi subur dan banyak ikan berkumpul di tempat tersebut.

\section{Uji similaritas}

Analisis data Uji similaritas menggunakan Levene's Test. Hasil Levene's Test diperoleh nilai signifikansi 0,963. Nilai signifikansi $>0,05$ maka kesimpulannya adalah terima $\mathrm{H}_{0}$ artinya antara spesies memiliki kecenderungan yang sama pada jenis makanan. Hal ini sesuai dengan penelitian Yusron dan Sjafei (1997), bahwa isi perut teripang genus Holothuria didominasi oleh diatom.

\section{Pengukuran kualitas air}

Suhu suatu perairan dipengaruhi oleh musim, lintang, ketinggian dari permukaan laut, waktu dalam hari, sirkulasi udara, penutupan awan serta kedalaman perairan. Organisme akuatik memiliki kisaran tertentu yang disukai untuk pertumbuhannya (Martoyo et al, 2006). Hasil pengukuran suhu air di Perairan Pulau Pramuka pada saat sampling dilapangan adalah $28-30^{\circ} \mathrm{C}$. Menurut Lewerissa (2009), kisaran suhu yang baik untuk pertumbuhan teripang adalah 27 $-30^{\circ} \mathrm{C}$. Peningkatan suhu dari kisaran optimum akan mempengaruhi biologi reproduksi dan kecepatan makan dari teripang itu sendiri bahkan teripang akan kehilangan selera makan sama sekali.

Hasil pengukuran kedalaman yaitu antara $0,5-0,9 \mathrm{~m}$. hal ini sesuai dengan habitat teripang karena teripang merupakan organisme laut yang mendiami daerah pasang surut hingga laut dalam. Menurut Notowinarno (1992) dalam Gultom (2004), kedalaman yang baik untuk pembesaran teripang berkisar antara 0,5 - 1 meter dan tidak mengalami kekeringan sehingga dihitung pada saat surut terendah.

Berdasarkan pengamatan yang telah dilakukan salinitas yang didapatkan adalah $31 \%$. Menurut Pawson (1976) dalam Aziz (1996), Holothuroidea dapat menyesuaikan diri pada salinitas 30-37 \%. Menurut James et al, (1988) dalam Hana (2011), teripang pada umumnya menyukai perairan yang bersih dan jernih. Perubahan salinitas melebihi 3 \%o dari kisaran ekstrim dapat menyebabkan terjadinya pengelupasan kulit yang dalam kondisi ekstrim dapat menyebabkan kematian teripang.

Hasil pengukuran derajat keasaman $(\mathrm{pH})$ pada lokasi penelitian didapatkan nilai 7. Menurut Wibowo et al, (1997), dimana nilai $\mathrm{pH}$ yang baik adalah 6,5 - 8,5, Maka dapat dikatakan untuk persyaratan derajat keasaman (pH) maka lokasi tersebut memenuhi syarat. 


\section{Kandungan substrat perairan}

Kehidupan teripang sangat dipengaruhi oleh substrat dan media air. Teripang biasanya hidup di daerah berpasir yang bercampur pecahan karang dan banyak ditumbuhi tumbuhan laut atau lamun. Pemilihan substrat bagi teripang senantiasa menyesuaikan berdasarkan ukuran partikel substrat, hal ini berhubungan dengan kebiasaan individu dewasa untuk mencari makan dari substrat (Gultom, 2004).

Lokasi sampling dilakukan pada daerah rataan terumbu karang yang didominasi oleh substrat pasir dan kecahan karang. Teripang yang ditemukan yaitu dari famili Holothuriidae, genus Holothuria. Hal ini sesuai dengan pendapat Hyman (1955) dalam Purnawati (2003), bahwa daerah tropis dengan suhu perairan hangat, jenis Holothuria sp. terdapat dalam jumlah yang banyak pada dasar berpasir terbuka atau sedikit tertutup oleh pecahan karang, potonganpotongan cangkang moluska dan tumbuhan.

Dilihat dari tabel kandungan substrat bahwa substrat dasar pada lokasi penelitian sebelah utara didominasi oleh gravel. Pada lokasi ini hanya ditemukan 1 teripang. Menurut Reseck (1979) dalam Yuana (2002), bahwa daerah gravel memiliki oksigen yang baik, sehingga organisme dapat memperoleh makanan dengan baik, tetapi teripang jarang ditemui pada daerah dengan tipe substrat gravel karena kurangnya kandungan organik dalam sedimen.

Pada daerah timur kandungan substrat didominasi oleh pasir. Pada lokasi ini ditemukan 4 individu teripang, lebih banyak dari pada lokasi utara. Pasir memiliki karakter khusus yang nantinya berpengaruh terhadap kebiasaan makan teripang, karena substrat dasar pasir kaya akan bahan organik. Menurut Pawson (1967) dalam Aziz (1996), teripang ordo Aspidochirotidae pada umumnya bersifat deposit feeder, dengan sumber makanan utamanya berupa kandungan zat organik dalam lumpur, detritus dan plankton. Menurut Gultom (2004), pada jenis substrat berpasir kandungan oksigen relatif lebih tinggi dibandingkan dengan substrat yang lebih halus. Pada substrat berpasir terdapat pori udara yang memungkinkan terjadinya percampuran yang lebih intensif dengan air diatasnya.

\section{Kesimpulan dan Saran}

Kesimpulan yang didapatkan dari hasil penelitian di Perairan Pantai Pulau Pramuka, Kepulauan Seribu mengenai Kebiasaan Makan Teripang adalah Jenis - jenis makanan teripang pada $H$. hilla, H. leucospilota dan $H$. impatiens yaitu Bacillariophyceae, Cyanophyceae, Chlorophyceae, Rotatoria, butiran pasir, larva Crustacea dan Ciliata dan jenis Bacillariophyceae memiliki nilai index of preponderance > $25 \%$ sehingga Bacillariophycea merupakan makanan utamanya.

\section{Daftar Pustaka}

Aziz, A. 1996. Makan dan Cara Makan Berbagai Jenis Teripang. Oseana, Volume XXI, Nomor 4, $1996: 43$ - 59.

Effendie, M. I. 1979. Metoda Biologi Perikanan. Yayasan Dewi Sri, Bogor: vii + $112 \mathrm{hlm}$.

. 2002. Biologi Perikanan. Yayasan Pustaka Nusatama. Yogyakarta. $163 \mathrm{hlm}$.

ETI BioInformatics. 2006 Marine Species Identification Portal Holothuria impatiens. Diakses pada tanggal 14 September 2012 17:39. WIB http://species-identification.org/species.php?species_group=nasc\&id=64

Gultom, C. P. W. 2004. Laju Pertumbuhan Dan Beberapa Aspek Bio-ekologi Teripang Pasir (Holothuria scabra) Dalam Kolam Pembesaran Di Laut Pulau Kongsi, Kepulauan Seribu, Jakarta Utara. Program Studi Ilmu Kelautan IPB. Bogor.

Hana. 2011. Evaluasi Pemacuan Stok Teripang pada Habitat Konservasi Lamun Pulau Pramuka, Kepulauan Seribu, Jakarta. Departemen Manajemen Sumberdaya Perairan. Fakultas Perikanan Dan Ilmu Kelautan. Institut Pertanian Bogor. Bogor.

Haryadi, S. 1983. Studi Makanan Alami Ikan Mujair, Nila, Lele, dan Ikan Mas diSitu Ciburuy, Kabupaten Bandung. Fakultas Perikanan IPB, Bogor.

Haryanto, Y. 2011 Analisis Faktor-Faktor Pendukung Penguatan Calon Penyuluh Pertanian Ahli Untuk Pembangunan Ketahanan Pangan (Kasus Sekolah Tinggi Penyuluhan Pertanian Bogor). Sekolah Pascasarjana Institut Pertanian Bogor, Bogor.

Lewerissa, Y. A. 2009. Pengelolaan Teripang Berbasis Sasi Di Negeri Porto Dan Desa Warialau Provinsi Maluku. Sekolah Pascasarjana Institute Pertanian Bogor. Bogor.

Martoyo J, Aji N, \& Winanto T. 1994. Budidaya Teripang. Penebar Swadaya. Jakarta. 72 hlm.

Purnawati, B. 2003. Distribusi Teripang Kelas Holothuroidea Di Perairan Taman Nasional Laut Kepulauan Seribu. Program Studi Ilmu Kelautan. Fakultas Perikanan Dan Ilmu Kelautan. Institut Pertanian Bogor. Bogor.

Purwati, P dan Wirawati, I. 2009. Holothuriidae (Echinodermata; Holothuroidea, Aspidochirotida) perairan dangkal Lombok Barat, Bagian I. Genus Holothuria, J Oseanol 2(21): 1-25.

$\begin{array}{llllllllll}\text { Setiawan, J. 2010.Teripang. Diakses pada tanggal } & 8 & \text { Maret } & 2012 & 11.00 & \text { WIB. }\end{array}$ http://makalahteripang.com/2010_10_01_archive.html

Setyastuti, A. 2009. Sea cucumber (Echinoderata: Holothurioidea: Stichopodidae, Holothuriidae, Synaptidae) Dari Seram Bagian Barat, Maluku, Indonesia, Koleksi Pada Bulan Juli 2007. Technical Implementation Unit for Marine Life Conservation. Ambon. 
Wibowo, S., Yunizal, E. Setiabudi, M. D. Erlina dan Tazwir. 1997. Teknologi Penanganan Dan Pengelolaan Teripang (Holohuroidea). Instansi Penelitian Perikanan Laut Slipi. Balai Penelitian Perikanan Laut. Pusat Penelitian dan Pengembangan Perikanan. Jakarta, 37 hal.

Yuana, S. 2002. Kelimpahan dan Distribusi Teripang (Holothuroidea) di Perairan Pantai Kepulauan Karimun. Universitas Diponegoro. Semarang.

Yusron, E dan Sjafei, S. D. 1997. Studi Analisis Makanan Dari Beberapa Jenis Teripang (Holothuroidea) Di Perairan Pulau Ambon. Institut Pertanian Bogor. Bogor. 